\title{
PERSRERT Ś
}

Volume 2/Nomor1

Juli - Desember 2019

E-ISSN 2656-050X

\author{
RETRACTED : DISEMINASI INFORMASI PUBLIK OLEH HUMAS \\ KEMENTERIAN KELAUTAN DAN PERIKANAN DALAM MENINGKATKAN \\ PUBLIC AWARENESS \\ (Studi Kasus Permen KKP No.2 Tahun 2015 Mengenai \\ Larangan Penggunaan Pukat Hela dan Pukat Tarik)
}

Mega Purnama Sari, Kusumajanti

Program Studi Ilmu Komunikasi UPN Veteran Jakarta

kusumajantisuwarto@gmail.com,megapurnama6@gmail.com

\section{Retracted}

Editor menyampaikan bahwa terjadi kesalahan berupa miskomunikasi dengan penulis dikarenakan antrian untuk publikasi di Ekspresi dan Persepsi : Jurnal Komunikasi dan penulis tidak menginformasikan kepada pengelola bahwa tulisan yang sama sudah dipublikasikan di Jurnal Komunikasi, Media dan Informasi pada Vol. 7, No. 3 Hal. 91-104, November 2018. Oleh karena itu arikel ini ditarik dengan pertimbangan tersebut.

Demikian keterangan ini dibuat agar dimanfaatkan sebagaimana mestinya dan informasi lebih lanjut dapat menghubungi pengelola Eskpresi dan Persepsi : Jurnal Ilmu Komunikasi pada link: https://e journal. upnvj. ac. id/index. php/JEP. 